Organo- and

Biocatalysis

\title{
Reducing Ketones with Carrots
}

Key words

daucus carota

3-amino ketones<smiles>[R]C1CC(=O)CN([Tl])C1</smiles>

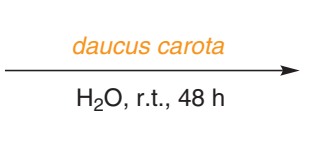<smiles>O[C@@H]1CNN(P)C1</smiles>
up to $83 \%$ yield

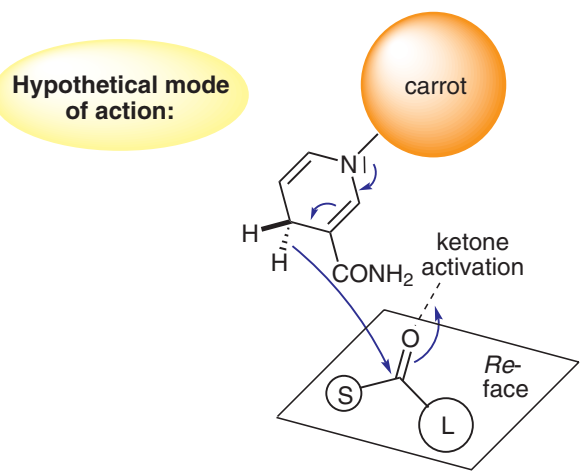

er up to $99: 1$

$\beta$-keto esters

keto reduction

Selected examples:<smiles>O[C@H]1CCCN([18OH])C1</smiles><smiles>CN1C[C@H](O)c2ccccc21</smiles><smiles>O=C(O)C1CC(O)CN1[18O]</smiles>

$78 \%$ yield er $=96: 4$<smiles>CCOC(=O)[C@@H]1CN(C(=O)OCc2ccccc2)CC[C@H]1O</smiles>

$91 \%$ yield er $($ syn $)=95.5: 4.5$ $\operatorname{dr}($ syn/anti $)=60: 40$

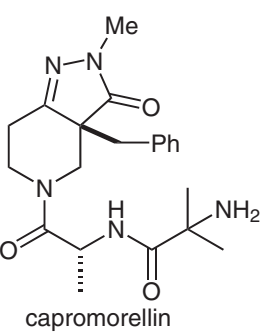

capromorellin
Significance: The carrot-mediated keto reduction of cyclic 3-oxoamines is reported. The straightforward synthetic procedure utilizing daucus carota slices in its unmodified form in aqueous media delivered the products in high yields and enantioselectivities. The mechanism of this biochemical transformation presumably proceeds via a pro- $(R)$ hydride transfer from the NADH present in the plant cells, which is in accordance with a Prelog model previously discussed in the literature (Glasfeld and co-workers Proc. Natl. Acad. Sci. USA 1991, 88, 8420). The reduction of cyclic oxo-amines derived from proline led to products with opposite configuration on the newly formed stereocenter.
Comment: In terms of sustainability, biochemical transformations applying renewable primary products are highly important. In this context, the idea of using carrots for the reduction of ketones originally proposed by Blanchard and van de Weghe (Org. Biomol. Chem. 2006, 4, 2348) is an interesting approach. The contribution by Cossy and coworkers extends the scope of this methodology to rather complex molecules, which were reduced under mild reaction conditions. Since the catalytic procedure relies on the use of whole cells, no cofactor addition or recycling is needed. Moreover, a synthetic application of the method has been shown in a synthesis towards the anti-aging drug capromorellin. 